\title{
Two sides of the coin
}

\section{Tokyo \& Washington}

JAPANESE plans for a $\$ 1,000$-million international project in manufacturing technology have been further delayed by the postponement, at the request of the United States, of a meeting arranged for last week.

If nothing more, the delay reflects big differences in the way research and development policy is set in Japan, the United States and the European Communities (EC). But regional chauvinsm may also be involved.

The project, called Intelligent Manufacturing Systems (IMS), is for the development of the automated factories of the future, and would be supported to the tune of 60 per cent from Japan. Partnership has been invited from the United States and the EC.

The Ministry of International Trade and Industry (MITI) had planned to discuss reactions to the Japanese proposal in Tokyo last week, but the US Department of Commerce requested a further postponement of a meeting originally arranged for June. It will now take place in November, even though the EC have already put out their own proposal.

Department of Commerce officials reject Japanese complaints that they are dragging their feet. Mark Lieberman, Deputy Assistant Secretary for Technology Policy, points out that, unlike Japan, where MITI coerced some companies into the project, the United States cannot dictate industrial policy.

IMS was first proposed by Hiroshi Yoshikawa, head of Tokyo University's Faculty of Engineering, and won backing from MITI and Japanese industry in January (see Nature 343, 496; 1990). It will develop standardized manufacturing systems that are fully computerized from the design stage through to the retailing and distribution of the finished product. MITI proposed that the project organization should be funded 60 per cent by Japanese government and industry, with the remainder coming from Europe and the United States.

More than 60 major Japanese manufacturers have contributed funds to help launch the project. Two US companies, Rockwell International and United Technology Pratt and Whitney, also signed up, but then had to pull out after the US Department of Commerce heard that the US Society of Manufacturing Engineers was to act as the North American secretariat. The department insisted that US participation be organized instead under the terms of the US-Japan Science and Technology Agreement.

Lieberman says the original proposal would not have produced a "balanced, symmetrical, win-win situation", and that "most of the benefits would have flowed in a direction which our US companies are not very comfortable with".

MITI officials have expressed surprise at this reaction, saying they had hoped the project would end complaints of lack of foreign access to Japanese research, particularly that carried out by governmentled consortia, and provide a way to pay back Japan's "technological debt" to the West by generously providing Japanese expertise in manufacturing. But US and EC opinion does not accept that Japan is really ahead in computer-integrated manufacturing (CIM).

According to Fred Nichols of the Washington-based National Coalition for Advanced Manufacturing, US universitybased research, driven by NASA and Department of Defense requirements, is more sophisticated than that of Japan, especially in visual simulation, artificial intelligence and sensor technology. These are essential talents for computerized manufacturing, together with the traditionally US skills in the large-scale software integration. And in some instances, Japanese companies are unaware of developments elsewhere.

EC officials admit that Japan clearly has a lead in the rapid conversion of design into manufactured products, but in their draft report argue that this is "due to cultural factors - stable career structures, shared objectives and experiences which promote communication, collective decision making and staff movement across departmental boundaries — which could not readily be reproduced in the West".

Rather than a central organization for IMS, the EC report proposes a decentralized project, much like ESPRIT and other EC research projects, with each research consortium financed from its region of origin (Europe, the United States or Japan). Collaboration between the EC, Japan and United States should be carried out between partners of "equal weight", the document states, and research should begin with a "pilot" project on a few "limited and uncontentious" studies once there is a detailed agreement on intellectual property rights.

Kenzo Inagaki, deputy director of MITI's industrial machinery division, claims the European proposal is now "very close" to Japan's way of thinking. But it is hard to see how MITI can merge its ideas with those of the United States and Europe. The United States is certain to oppose control over industrial policy by a central body, but just such a MITI-style body has already been put in place in Tokyo with the several million dollars contributed by industry.

David Swinbanks \& Alun Anderson

\section{Australian law finds balance}

\section{Sydney}

THE Australian federal government last week drew the line at patenting human beings. But in a debate intended to amend patent law to accommodate innovations in biology, it agreed that some other forms of life should be subject to patent law.

In last week's parliamentary debate, Senator John Coulter proposed an amendment to the Patents Act of 1952 that would have prohibited the patenting of living animals, plants and microorganisms unless assessed by a committee consisting of geneticists, people specialized in ethics and representatives from consumer groups. This amendment was defeated largely on the grounds that it might prevent the patenting of genetically engineered vaccines.

Instead, an alternative amendment proposed by Senator Brian Haradine that human beings and their biological processes for generation should not be patentable inventions was accepted.

Coulter dismissed the accepted amendment as "obscure" while Haradine agreed that it "does not protect against abuse". Under this new bill, the patenting of living things will be solely at the discretion of the Patents Office staff without reference to parliament, bioethics committees, the public or the constitution.

But the Institute of Patent Attorneys of Australia, in a report for the House of Representatives Standing Committee on Industry, Science and Technology, takes an opposing stance and argues that "if the categories of patentable subject matter are altered to exclude living organisms, industry and other research organizations in Australia engaged in legitimate and worthwhile research programmes would be seriously disadvantaged".

Australia now stands somewhere between the United States and Europe in the scope of its laws governing the patenting of living organisms. In 1980, the US Supreme Court ruled that "everything under the Sun made by man" is eligible for a patent, as long as an invention is useful, novel and non-obvious. And in 1988 the world's first animal patent was awarded for an oncogene mouse developed at Harvard (see Nature 332, 668; 1988).

But in Europe, the European Patent Convention signed by 13 European members of the Council for Europe forbids patenting of "plant and animal varieties", which may nevertheless be registered and copyrighted. Although definition of "varieties" remains open to question, an attempt by Harvard to patent the oncogene mouse in Europe was rejected in 1989 (see Nature 340, 85; 1989).

Tanla Ewing 